\title{
Formation of Character of Environmental Care Based on Local Wisdom in Surakarta
}

\author{
Wendy Librata Ratna Manikam ${ }^{1}$, Dewi Gunawati ${ }^{2}$, Triyanto ${ }^{3}$ \\ ${ }^{1}$ Student of Post Graduate Civic Education, Sebelas Maret University, Indonesia \\ ${ }^{2,3}$ Lecturer of Post Graduate Civic Education, Sebelas Maret University, Indonesia \\ wendyppkn@gmail.com
}

\begin{abstract}
One of the problems regarding environmental damage is human's bad behavior towards the environment. This relates to the character or personality of humans who do not care about environmental sustainability. Environmental damage due to human behavior will bring adverse effects or threaten human survival. The method used in research uses a qualitative approach. As for the results of the research, first, the formation of environmentally friendly character based on local wisdom can be done through education in schools. The teacher provides education or teaching by taking Javanese cultural value related to preserving the environment. Family, through parents provides advice and messages relating to the formation of environmental care character by taking the values contained in local wisdom. Within the scope of the RT programs can be run that lead to environmental hygiene concerns as well as making slogans taken from ancestral advice that can encourage environmental care.
\end{abstract}

Keywords: Character; local wisdom; environmental sustainability

\section{Introduction}

Environmental cleanliness is still a problem of the Indonesian nation both locally and nationally. Examples that can be mentioned here are the problem of garbage and pollution both air and water. Littering like on the road, in the gutters, and in rivers has its own impact on humans. Waste that is not managed properly will also cause problems, such as damage to ecosystems in the river and health problems.

One of the causes of the problem of environmental cleanliness is due to the character or character who lacks concern for environmental hygiene and health in the community. Personalities that lack empathy for the environment will give birth to behaviors and attitudes that can be said to damage the health of the environment. Careless littering behavior is a manifestation of bad character related to concern for environmental cleanliness. This is sometimes not realized by the public. This kind of situation will get worse and worse because the bad habit will continue from generation to generation without any effort to overcome it.

Bad behaviors that endanger the health of the environment such as littering, indifferent to environmental cleanliness will threaten human survival itself. Therefore, it is very important to make efforts to shape the character of environmental care in the community, especially towards the younger generation or the next generation.

The character of caring for the environment can be formed through the inculcation of local wisdom values. Local wisdom has certain values that can be used as a means of building character, especially those relating to attitudes or behaviors that care about environmental cleanliness. The noble values of local wisdom are instilled in order to shape one's behavior, especially with regard to environmental health. This is confirmed by Foster and Anderson (in Djoyomartono, 2004: 15) which states that health is related to behavior. Human behavior tends to be adaptive. Conscious or unconscious behavior is planned to maintain survival and improve the welfare of members of each group. Healthy behavior can be seen as a rational response to things that can cause illness. 
Character according to Alwisol (in Zubaedi 2011: 12) is interpreted as a picture of behavior that emphasizes the value of right-wrong, good-bad, both explicitly and implicitly. Character differs from personality, because the notion of personality is freed from value. Although is both personality (personality) and tangible character of behavior that is shown to the social environment.

Lickona (in Samani and Hariyanto 2012: 44) defines character education as a genuine effort to help someone understand, care, and act on the basis of ethical values. Lickona simply defines character education as a consciously designed effort to improve the character of students. In the grand design of character education, character education is a process of civilizing and empowering noble values in the environment of the education unit (school), family environment, and community environment (Zubaedi 2011: 17).

More or less the same opinion conveyed by Heri Gunawan (2012: 23) which states that the character of education is the conscious and full effort of the teacher to teach students the value of drawing conclusions wisely and to practice them in real life to make a positive contribution to their community. (in Haryanto and Akhirin, 2018: 519).

Some of the opinions above can be taken the understanding that character education is an effort to form a personality that has an orientation to noble, noble values, which in the next stage will give birth to attitudes and behaviors that are commendable too. When associated with environmental care, the character or personality leads to behaviors and attitudes that can support the realization of environmental sustainability. In other words, the behavior and actions that are born do not tend to damage or harm the environment.

Human behavior towards the environment is influenced by a number of basic factors, supporters, drivers and perceptions, as well as environmental factors, both the physical environment and the social environment. Among the factors of influence are the basic factors, which include worldview, customs, beliefs and habits of the community. Supporting factors include education, employment, culture and social strata. As a driving factor includes the touch of electronic media is both written, counseling, religious leaders and the community. The extent to which information is absorbed by a person depends on the psychological dimensions and perceptions of the environment, henceforth it will be reflected in the order of behavior. (Su Ritohardoyo, 2006: 51)

Character can be formed through teaching that draws on the values of local wisdom, especially those relating to environmental care. The ancestors already have their own way of protecting nature and the environment. In this regard, Koentjaraningrat states that, in maintaining balance and harmony with the natural surroundings, people (Java) have certain beliefs related to superanatural powers. (1974: 221). But that does not mean the formation of these characters is done in a magical or occult way. There are values contained in Javanese tradition or culture in caring for nature and its environment. These values can be taken and taught to the community.

Teaching can be done through formal education such as schools. Furthermore, schools can run programs related to maintaining environmental cleanliness. According to the Ministry of National Education (in Fitri 2012: 25) the objectives of character education include: (1) developing the potential of the heart / conscience / affective students as human beings and citizens who have religious cultural values of the nation; (2) developing the habits and behavior of students who are praiseworthy and in line with universal values and national cultural traditions that are religious; (3) instilling the spirit of leadership and responsibility of students as the next generation of the nation; (4) developing the ability of students to become 
independent, creative, and national-minded human beings; (5) developing the school life environment as a learning environment that is safe, honest, full of creativity and friendship, as well as with a high sense of nationality and full strength (dignity).

The above statement implies that character education is very important to be given, especially through education channels or school institutions for the creation of future generations who have noble personalities, useful for their environment. Some of the points mentioned above reflect the hope that future generations will have behaviors that are appropriate to their culture and religion. This means that religion and culture have or teach noble values for life, including the environment.

The formation of environmental care characters must also get support from the family. The family environment is also important in shaping the character of caring for the environment. Teaching or advice can be conveyed by parents by taking local wisdom values related to caring for the environment. In addition to schools and families, the surrounding environment or the community also has a large role in shaping the character of its citizens so that they have the mental and spirit to maintain the cleanliness of their environment.

In addition to the family environment, the environment or the community also plays a role in shaping the character of caring for the environment. This can be supported by the community for example through institutions at the village level to the RT to disseminate policies relating to environmental care.

This study seeks to examine the efforts to form a character of environmental awareness based on local wisdom in Surakarta. Javanese people are already known to have a culture or tradition that contains noble values including how to care for nature and the environment. Character formation related to environmental problems is interesting to study, as revealed by Rahmawati (2014: 2), that character building is needed in an effort to overcome the problems faced by this country, one of which is environmental damage, one of the problems faced by the Indonesian people.

\section{Methodology}

This type of research is descriptive with a qualitative approach to the method of literature study. This approach was chosen because the author wants to explain the theories and findings from the search for literature related to the efforts of character building an environment based on local wisdom.

The approach used in this study is a qualitative approach. Ghony, M. Djunaidi and Fauzan Almansur, (2012: 25) suggested that this qualitative approach was aimed at describing and analyzing phenomena, events, social activities, attitudes, beliefs, perceptions and thoughts of individuals individually and in groups. Bogdan and Taylor in Lexy J. Moleong (2007: 4) explain that qualitative methodology is a research procedure that produces descriptive data in the form of written or oral words from people and observable behavior.

The final results of the qualitative research are outlined in the form of a written report. Qualitative research results are strongly influenced by the views, thoughts and knowledge of researchers. The research report will contain data excerpts to illustrate the presentation of the report. The data may come from interview scripts, field notes, photos, videotapes, personal documents, notes or memos and other official documents. (Moleong, 2007: 11). 


\section{Discussion}

Efforts to build character, especially for future generations such as school-age children, require the participation of various parties such as educational institutions or school institutions, the family environment, and the wider community. This is done so that the process of instilling noble values or local wisdom can be done properly and can penetrate into the personal children who really have concern for the environment. Related to this matter Dahliani revealed that traditional values harmonize human life by respecting, maintaining and preserving the natural environment. That can be seen with the improvement and mutual support, the point is to understand the abilities and potential of the nature in which they live; and manifested as a tradition. (Expertise, 2015: 159).

\subsection{Instilling the value of local wisdom through schools}

The school is an institution or institution that is not only a place to seek academic knowledge, but also as a forum for forging and shaping the personality of children or students. Pragmatic knowledge will certainly be obtained at school but teachers and educators have a responsibility in shaping the personality of students. In the context of education, school culture is a pattern of behavior and ways of action that are automatically formed and become an internal part of community education. The basis of behavior and action are social norms, school rules, and policies at the local level. These three components are not only formed by formal expressions such as the rule of law, but also by the spontaneous actions of its members in acting, thinking, and drawing conclusions in real life. (Kusuma, 2011: 5).

Based on the above statement, it can be taken the understanding that schools have an important role in the formation of character or personality. This is possible because education contains rules, values, or regulations in which all components will be followed by all school members, especially students.

Opinions about school institutions related to character formation, expressed by Megawangi (2004: 25) which states that various opinions of child education experts, it can be concluded that the formation of human character (personality) is determined by two factors, namely nature (natural factors) and nurture ( socialization and education). The influence of nature, religion teaches that every human being has a tendency (nature) to love goodness. But this nature is potential, or has not been manifested when the child is born. The phrase implies that a person's personality or character has at least two factors, namely natural factors and educational factors. The first factor can be said as innate capital that may already be inherent in a person naturally, while the education factor can refer to the understanding that a person's personality can be formed through education, for example at school. That is, through an educational institution called a person's character school can be formed in accordance with the vision and mission of the school.

In connection with the formation of the character of environmental care based on local wisdom, teachers as educators must instill the values of local wisdom related to environmental preservation. Javanese culture has values that can be used as a basis or footing to shape student character. Nasruddin Anshoriy and Sudarsono (2008: 40-41) revealed several teachings contained in Javanese culture, such as: 1) Gusti Allah, 2) Ingkang Akaryo universe, 3) Ingkang Murbeng Dumadi, 4) Hyang Suksma Adiluwih, 5) Hyang maha Suci, 6) Sang Hyang Manon, 7) Ageman Aji Religion, and 8) Wiradat Nature. All of this is a 
guideline for Javanese people to behave, so that they always consider the magnitude of the Gusti Allah's Power and must guard whatever they have created.

Introducing Gusti Allah (God) who created the universe, the universe, implies that living things, especially humans, have the responsibility of caring for the universe. In a smaller scope is caring for and protecting the surrounding environment. By providing teaching that is based on locality values, it is hoped that it can form awareness among school students about the importance of keeping the environment clean, healthy, and comfortable so as not to endanger or disturb living things, especially humans.

Other values that exist in Javanese culture are memayu hayuning bawono, which has the responsibility of maintaining and caring for the balance of nature. Things that have the potential to damage the environment will be prevented. Attitudes and behaviors that can damage the environment can be avoided. Character cares about environmental health, at least not behaving that can threaten environmental sustainability. This behavior can be implemented as simple as throwing trash in its place, getting used to a healthy life and so forth.

As a form of efforts to shape the character of caring for the environment, the school as a formal educational institution can run programs that will encourage students to have a sense of sympathy and empathy for the environment, especially those related to environmental health.

To be effective, school-based character education programs need broad support from all stakeholders in the community - educators, parents, community leaders, youth service groups, businesses and religious and charitable groups. According to Lickona, when a comprehensive approach to character education is used, a positive moral culture is created in schools - a total school environment that supports values taught in the classroom. This is achieved through principals' leadership, school discipline, a sense of togetherness, democratic student governance, moral community among adults and opportunities to overcome moral problems. The school recruits parents and the community as partners and fosters care outside the classroom by using exemplary inspiration and opportunities for community service to help students learn to care by paying attention. (Pala, 2011: 28).

\subsection{Family environment}

The family is an important part in shaping the character of the child. This is possible because parents and children can communicate more intensely compared to others. This communication parents or other family members can provide advice to children relating to maintaining a clean and healthy environment. Parents can shape the mental and character of children to protect or preserve the environment through instilling the values of local wisdom, in this case Javanese culture.

Parents can directly control the behavior of children, set an example for children, especially those related to environmental cleanliness. Parents who have bad habits, such as littering at home, then the behavior will usually be followed by their children. Conversely, if parents always maintain cleanliness, the child will naturally imitate or emulate him. This will facilitate the process of forming the character of children to care about environmental cleanliness. As explained by Noor (2010: 41) which states that the family is the most important social environment for the personal development and formation of children. It is also a place for children's guidance and training since their very young lives. It is expected from one's family to live their lives mature and mature. 
The above statement clearly shows that the role of the family is very important in shaping the character of the child. Of course the locality values given to children are not limited to verbal statements but implementation or role models are needed that lead to the formation of a caring character for the environment, for example parents show empathy to the environment such as throwing trash in its place, cleaning sewers or clogged drains, and so forth.

\subsection{Surrounding environment}

The surrounding environment is a place for people to interact with each other. Community environment in the smallest scope is the level of the neighborhood (RT). Thus the habit of environmental cleanliness can be promoted through programs at the RT level, which of course need to involve local community leaders, youth clubs, and also all existing community members. As Megawangi (2004: 27) revealed, that the influence of Nurture, environmental factors, namely the effort to provide education and outreach was very instrumental in determining the "fruit" as what will be produced by a child. The statement proves that the environment in which a person lives can affect his personality. In the context of character building, the environment also plays a role, namely by conducting educational socialization that leads to caring for the environment.

Humans must always strive to maintain and maintain the integrity of their environment. A clean and healthy environment will bring great benefits to the lives of the people themselves. Conversely, a dirty environment will potentially have a negative impact on the people who live around it. That is, environmental damage will threaten the lives of many people. Therefore, it has become the responsibility of humans to preserve the environment. Related to this, Sumirat (2002: 34), explained that naturally humans live interacting with the environment. Starting is from humans breathing, taking the air that is around them every second, eating from the food produced from those around them, as well as drinking, and their activities. All depends on the existing social, cultural and environmental. Because human has a close relationship is with their environments.

\section{Conclusion}

Based on the description above, it can be concluded that the formation of environmental care characters can be done through educational institutions such as schools, family environments, and the surrounding environment. Schools shape the character of caring for the environment by instilling local wisdom values related to how ancestors or ancestors care for nature, or interpreting the teachings contained in Javanese culture to be implemented in school programs in maintaining and maintaining environmental cleanliness.

The family environment plays a role through parents to provide education and instilling ancestral values related to environmental care. While the surrounding environment, for example through RT institutions can run programs related to environmental cleanliness. The formation of an environmentally friendly character based on local wisdom can be given at community level meetings. Make slogans that can touch people's awareness about the importance of protecting and caring for the environment. 


\section{References}

Dahliani. (2015). Local Wisdom In Built Environment In Globalization Era. International Journal of Education and Research.

Ghony, M. Djunaidi and Fauzan Almansur. (2012). Metodelogi Penelitian Kualitatif. $1^{\text {st }}$ Edition. Yogyakarta: Ar-Ruzz Medi.

Haryanto, Akhirin. (2018). Building Students' Character Through Integrated Teaching Learning Activities at Madrassa. PROCEEDINGS - International Conference Internationalization of Islamic Higher Education Institutions Toward Global Competitiveness. Semarang, Indonesia.

Koentjaraningrat. (1994). Kebudayaan Jawa. Jakarta: Balai Pustaka

Megawangi, Ratna. (2004). Pendidikan Karakter. Jakarta: Indonesia Heritage Foundation.

Moleong, Lexy J. (2007). Metodelogi Penelitian Kualitatif. Bandung: PT. Remaja Rosdakarya

Nasruddin Anshoriy and Sudarsono. (2008). Kearifan Lingkugan, Dalam Perspektif Budaya Jawa, Yayasan Obor Indonesia.

Noor, Sofia Retnowati. (2010). Wanita Dalam Keluarga Islam. Majalah Qalam, Tazkiyah An-Nafs.

Pala, Aynur. (2011). The Need For Character Education. International Journal Of Social Sciences And Humanity Studies.

Rahmawati, Sri Utami. (2014). Meningkatkan Karakter Peduli Lingkungan Melalui Sekolah Berbudaya Lingkungan Hidup. Bandung.

Samani, Muchlas dan Hariyanto. (2012). Konsep dan Model Pendidikan Karakter. Bandung: PT Remaja Rosdakarya.

Slamet. Juli. Sumirat. (2002). Kesehatan Lingkungan. Bandung: Gajah mada University PRESS.

Su Ritohardoyo, (2006). Bahan Ajar Ekologi Manusia. Program Studi Ilmu Lingkungan. Sekolah Pascasarjana: UGM, Yogyakarta

Zubaedi. (2011). Desain Pendidikan Karakter, Konsepsi dan Aplikasi dalam Lembaga Pendidikan. Jakarta: Kencana. 